This manuscript is contextually identical with the following published paper:

Vitál Z, Józsa V, Specziár A, Mozsár A, Lehoczky I, Kovács B, Hliwa P, Boros G (2017) Source of bigheaded carp (Hypophthalmichthys spp.) in Lake Balaton, Hungary: natural recruitment or continuous escapement from aquaculture? Inland Waters. 7(2) pp. 218-226. DOI 10.1080/20442041.2017.1319546

The original published PDF available in this website:

http://www.tandfonline.com/doi/full/10.1080/20442041.2017.1319546

\title{
Source of bigheaded carp (Hypophthalmichthys spp.) in Lake Balaton, Hungary: natural recruitment or continuous escapement from aquaculture?
}

Zoltán Vitál, ${ }^{\mathrm{a}}$ Vilmos Józsa, ${ }^{\mathrm{b}}$ András Specziár, ${ }^{\mathrm{a}}$ Attila Mozsár, ${ }^{\mathrm{a}}$ István Lehoczky, ${ }^{\mathrm{c}}$ Balázs Kovács, ${ }^{\mathrm{d}}$ Piotr Hliwa, ${ }^{\mathrm{e}}$ and Gergely Boros ${ }^{\mathrm{a}}$

${ }^{a}$ MTA Centre for Ecological Research, Balaton Limnological Institute, Tihany, Hungary; ${ }^{b}$ NARIC Research Institute for Fisheries and Aquaculture, Szarvas, Hungary; ${ }^{c}$ Research Centre for Farm Animal Gene Conservation, Gödöllö, Hungary; ${ }^{\mathrm{d}}$ Department of Aquaculture, Szent István University, Gödöllő, Hungary; ${ }^{\mathrm{e}}$ Department of Ichthyology, University of Warmia and Mazury, Olsztyn, Poland

CONTACT: Zoltán Vitál vital.zoltan@okologia.mta.hu

\begin{abstract}
The worldwide spread of bigheaded carp (Hypophthalmichthys spp.) is considered an ecological threat and problem in many countries. The aim of this study was to consider the likelihood of bigheaded carp reproduction in Lake Balaton and its catchment area (Hungary). The within-year trends of gonadosomatic index values show that female bigheaded carp increase ovary masses from spring until midsummer, after which a decline is typical. This trend may indicate bulk egg release, but the lack of a sharp drop in fecundity (number of eggs
\end{abstract}


in the ovary) values during and after the potential spawning period suggests that a general and considerable ovary evacuation does not likely explain the declining gonadosomatic index values. Rather, it is more probable that female bigheaded carp resorb their eggs, supported by the presence of atretic oocytes in the ovaries after the potential spawning season. In turn, postovulatory follicles were present in the posterior ovary segments of 2 individuals, indicating that mature eggs were released by some females. The evidence of sporadic egg release does not necessarily imply that successful reproduction has occurred, however. The genetic analyses showed remarkable deviation from Hardy-Weinberg equilibrium within the stock, suggesting that bigheaded carp do not constitute a natural reproductive community in Lake Balaton. Thus, the present bigheaded carp stock in Lake Balaton likely derives primarily from external origin (i.e., from the surrounding fish ponds).

KEYWORDS Asian carp; fecundity; gonado-somatic index; histology; invasive fish; reproduction

\section{Introduction}

Bighead carp (Hypophthalmichthys nobilis Richardson 1845) and silver carp (H. molitrix Valenciennes 1844) are native to the large lakes and rivers of China and the Asian territories of Russia. These fishes and their hybrids (collectively referred as bigheaded carp or filterfeeding Asian carp) have been introduced to several countries worldwide since the 1950s (Jennings 1988, Kolar et al. 2007). The usual goals of bigheaded carp introduction and stocking outside of their native range were to increase fish production and to improve the water quality in eutrophic and hypertrophic waterbodies, under the assumption that these fish species (especially silver carp) reduce eutrophication by removing phytoplankton from the water column (Cremer and Smitherman 1980, Xie and Liu 2001). A number of studies cast 
doubt on this idea, however, and report that bigheaded carp are conducive to elevated dissolved nutrient concentrations in the water column, reduce zooplankton rather than phytoplankton biomass, and often contribute to the deterioration of water quality (e.g., Mátyás et al. 2003, Lin et al. 2014).

Bigheaded carp were introduced to Lake Balaton (Hungary) in 1972 to increase fishery yields and control serious planktonic eutrophication. Before the initial stockings, silver carp fingerlings were imported to Hungary in the 1960s from the former Soviet Union and China, but bighead carp individuals concurrently arrived in Hungarian hatcheries (Kolar et al. 2007). Introduced fish arrived in Lake Balaton presumably from a pure genetic line culture of silver carp in 1972, but later events are somewhat unclear. Márián et al. (1986) noted that Hungarian researchers had started an extensive program to hybridize bighead carp and silver carp. As a result of this attempt, the original and pure fish strains became "contaminated" with the genes of the other species. Accordingly, it cannot be assured that only pure silver carp were stocked into Lake Balaton during the 1970s and 1980s. Instead, it seems more probable that broodstocks in Hungarian hatcheries consisted of hybrid bigheaded carps with silver carp phenotypic traits, and mostly these fish were used to stock Lake Balaton. At present, most if not all of the bigheaded carp in Lake Balaton are Hypophthalmichthys hybrids (Boros et al. 2014, 2015); in this study we thus refer to all captured fish simply as "bigheaded carp."

The persistent bigheaded carp stocking did not significantly improve the water quality of Lake Balaton, and hence it was stopped and banned in 1983. Bigheaded carp biomass remained high after 1983, however, and has not declined during the past decades despite the intensive and continuous size-selective fishery that lasted until 2013 (Weiperth et al. 2014). Two reasonable theories can explain the source of new fish and the provenance of the present bigheaded carp stock in Lake Balaton. First, it can be assumed that fish escape regularly from surrounding aquaculture operations during water discharges or in flooding events, allowing 
various size-classes of bigheaded carps to arrive in Lake Balaton through the connected watercourses. The second option is that bigheaded carp may be able to reproduce in the lake or in the watershed, but this assumption contradicts the generally accepted opinion (Kolar et al. 2007) that these species require relatively long (at least $100 \mathrm{~km}$ ), undammed, free-flowing rivers for successful spawning and reproduction.

This study aimed to assess the likelihood of bigheaded carp reproduction in a large and shallow freshwater lake that lacks tributaries apparently feasible for spawning. Results of histological examinations, measurements on ovaries, and genetic analyses of the stock in Lake Balaton were considered to define the source of bigheaded carp recruitment that has maintained the stock's biomass at a relatively constant level throughout the past decades.

\section{Study site}

Lake Balaton is the largest shallow lake in Central Europe. It is situated in the Transdanubian region of Hungary and has a surface area of $596 \mathrm{~km}^{2}$, an average water depth $\sim 3.3 \mathrm{~m}$, and a catchment area of $5775 \mathrm{~km}^{2}$. Lake Balaton has 51 inflows of various sizes (one river and several smaller canals, streams, or brooks) and only one outflow, the Sió-canal. Although some of the inflows are relatively long (Fig. 1), it is questionable that these could serve as potential spawning and hatching grounds for bigheaded carp. The aforementioned watercourses are typically shallow, and several dams or other barriers prevent bigheaded carp migration upstream over longer distances. A number of aquaculture operations (the largest is Marcali-reservoir; Fig. 1) are found in the watershed of Lake Balaton stocked regularly with bigheaded carp (Hancz and Varga 2014) and could be potential sources of several invasive, nonnative fish species (Sály et al. 2011, Erős et al. 2012). 


\section{Methods}

\section{Sampling and sample processing}

Fish were captured from the eastern basin of Lake Balaton (Fig. 1) in 2011 (Mar-Nov) and 2013 (Apr-Oct) by the Balaton Fish Management Non-Profit Ltd, using size-selective gillnets (12 cm knot-to-knot mesh-size). Fish sampling was paused in July and August, according to local regulations. In addition, ovary sample collection for histological analyses was not possible in June and October 2011. We collected 112 bigheaded carp, 58 of which were female. After catching, fish were sacrificed rapidly (by severing the central nervous system), and then ovaries were removed from the abdominal cavity and tissue samples for DNA analysis were collected from the dorsal fins.

Standard body lengths $\left(\mathrm{L}_{\mathrm{S}}\right)$, total body lengths $\left(\mathrm{L}_{\mathrm{T}}\right)$, total body mass $\left(\mathrm{W}_{\mathrm{T}}\right)$, and ovary mass $\left(\mathrm{W}_{\mathrm{O}}\right)$ were measured. Fulton's condition factors (K; Nash et al. 2006) were calculated as follows:

$$
\mathrm{K}=\mathrm{W}_{\mathrm{T}}(\mathrm{g}) / \mathrm{L}_{\mathrm{T}}^{3}(\mathrm{~cm}) \times 100 .
$$

Gonadosomatic index $\left(\mathrm{I}_{\mathrm{G}}\right.$; the gonad's mass as a proportion of the total body mass) of female individuals was calculated as follows:

$$
\mathrm{I}_{\mathrm{G}}, \%=\left(\mathrm{W}_{\mathrm{O}}, \mathrm{kg} / \mathrm{W}_{\mathrm{T}}, \mathrm{kg}\right) \times 100 .
$$

To estimate fecundity, 3 subsamples (50 mg each) were taken from the medial-posterior segments of ovaries ( $n=29$; Fig. 2), and the number of eggs per unit ovary mass was counted under binocular microscope. Subsequently, total fecundity $\left(\mathrm{F}_{\mathrm{T}}\right.$; total number of eggs per ovary) and relative fecundity $\left(\mathrm{F}_{\mathrm{R}} ; \mathrm{F}_{\mathrm{T}}\right.$ divided by the individual's body mass) were calculated. 
In addition, histological examinations were performed on the ovaries of fish $(n=23)$ caught in 2011. Samples were taken from 3 different regions of ovaries: the anterior (closest to the head), the medial, and the posterior (closest to the genital pore; Fig. 2).

Samples of gonads were fixed in Bouin's solution for 24 hours and then were dehydrated through a series of ethanol solutions $(70 \%$ to $95 \%)$, immersed in xylene and finally embedded in paraffin blocks. The samples were sectioned (5-6 $\mu \mathrm{m}$ thickness) with a rotation microtome model RM 2155 (LEICA Microsystems, Wetzlar, Germany) and subsequently stained with haematoxyline and eosin (POCH S.A., Gliwice, Poland). Maturation of gonads was determined according to the Sakun and Butskaya (1963) scale and classified into 6 stages. Stage I: Oogonia are visible, after which oocytes enter a period of meiotic prophase and remain in diplotene stage, completely filling the germ cells with yolk. Stage II: The gonad contains mostly previtellogenic oocytes that gradually increase in diameter, and a number of nucleoli are located on the periphery of the nuclear membrane in the nuclei of cells. On the periphery of previtellogenic oocytes, single epithelial cells can be observed, forming the developing follicular membrane. Stage III: Visible oocytes can be observed in the ovaries with vacuoles in their cytoplasm, accumulating nutrients gradually. This phase is the beginning of trophoplasmatic growth, which corresponds to the vitellogenic period. Stage IV: This phase is the end of trophoplasmatic growth, in which oocytes are filled with nutrients. Stage V: Ovulation occurs, and the nucleus of the oocyte moves to the micropyle, forming the animal and vegetative poles. Stage VI: During this post-ovulatory period, ovaries are partially or completely empty and contain postovulatory follicles beside maturing and matured oocytes.

We performed genetic analysis to assess the potential deviation from the Hardy-Weinberg equilibrium and the rate of inbreeding within the stock. Tissue samples $(n=108)$ from the dorsal fins were stored in $96 \%$ ethanol at $-20{ }^{\circ} \mathrm{C}$ until DNA isolation, and DNA was extracted 
using the Qiagen DNeasy Blood and Tissue Kit (QIAGEN, Hilden, Germany) following manufacturer instructions. We used 10 autosomal microsatellite markers (Hmo01, Hmo02, Hmo03, Hmo13, Hmo33, Hmo34, Hmo36, Hmo37, Hmo39, and Hmo40; Gheyas et al. 2006) to assess the potential deviation from Hardy-Weinberg equilibrium. Microsatellite analyses were carried out as described by Gheyas et al. (2006), with some modifications (primers were fluorescently labeled with FAM, TET, and HEX fluorescent dyes and the length of different microsatellite alleles were assessed by running the multiplexed PCR products against GeneScan, 500 TAMRA, Applied Biosystems, Foster City, CA) by a 3130 Genetic Analyzer (Applied Biosystems, Foster City, CA). Results were visualized using GeneMapper 4.0 software (Applied Biosystems, Foster City, CA). The inbreeding coefficient for each locus was evaluated using the software Fstat 2.9.3 (Goudet 2001).

\section{Statistical analyses}

The relationships among $\mathrm{I}_{\mathrm{G}}, \mathrm{F}_{\mathrm{T}}$, and $\mathrm{F}_{\mathrm{R}}$ (response variables) and body size $\left(\mathrm{L}_{\mathrm{S}}, \mathrm{W}_{\mathrm{T}}\right)$, sampling date, and K (descriptor variables) were tested with analysis of covariance (ANCOVA), by using sampling date as factor (categorical variable) in the models. To avoid collinearity, the effects of descriptor variables were tested individually in separate models. Beta coefficients (i.e., the standardized regression slopes) were determined for each descriptor variable to compare the relative strength and direction of their relationships with $\mathrm{I}_{\mathrm{G}}, \mathrm{F}_{\mathrm{T}}$, and $\mathrm{F}_{\mathrm{R}}$. Statistical analyses were performed with StatSoft Statistica 7.0 and evaluated at $p \leq 0.05$ significance level.

MICRO-CHECKER 2.2.3 software (Van Oosterhout et al. 2004) was used to check the molecular genetic data for allelic dropouts, null alleles, and other possible genotyping errors. The observed and expected heterozygosity for all loci and assessment of deviation from the Hardy-Weinberg equilibrium were calculated by Markov Chain Monte Carlo exact test (Guo 
and Thompson 1992). GENEPOP on the web was used for calculations, (Raymond and Rousset 1995, Rousset 2008).

\section{Results}

Main body parameters and gonadosomatic index

The $\mathrm{L}_{\mathrm{S}}$ of the sampled fish ranged from 0.80 to $1.18 \mathrm{~m}$ (average [S.D]; 0.96 [0.07] $\mathrm{m}$ ), their $\mathrm{W}_{\mathrm{T}}$ varied between 12.80 and $35.00 \mathrm{~kg}(19.80$ [4.40] $\mathrm{kg})$, and $\mathrm{W}_{\mathrm{O}}$ ranged between 0.81 and $7.00 \mathrm{~kg}(3.54[1.18])$

Female bigheaded carp $\mathrm{I}_{\mathrm{G}}$ ranged from 6.2 to 29.4 (17.9 [4.7]). Average $\mathrm{I}_{\mathrm{G}}$ was typically low in early spring and increased remarkably until reaching peak values in June in both 2011 and 2013 (Fig. 3). Afterward, $\mathrm{I}_{\mathrm{G}}$ values declined gradually toward late summer and autumn and reached similar values to those found in the spring. This trend was typical in both 2011 and 2013. ANCOVA models confirmed that sampling date was a significant factor in influencing $\mathrm{I}_{\mathrm{G}}(p<0.01$; Table 1$)$, but $\mathrm{L}_{\mathrm{S}}, \mathrm{W}_{\mathrm{T}}$, and $\mathrm{K}$ had no significant effect on $\mathrm{I}_{\mathrm{G}}$ (Table 1).

\section{Fecundity}

Total fecundity of females ranged from $8.2 \times 10^{-5}$ to $3.7 \times 10^{-6}$ eggs $\left(2.2 \times 10^{-5}\left[8.2 \times 10^{-5}\right]\right)$, whereas $F_{R}$ varied between 42.4 and 176.8 (104.2 [41.3]). There was no significant relationship between descriptor variables $\left(\mathrm{L}_{\mathrm{S}}, \mathrm{W}_{\mathrm{T}}\right.$, and $\left.\mathrm{K}\right)$ and $\mathrm{F}_{\mathrm{T}}$ and $\mathrm{F}_{\mathrm{R}}$ (Table 2 and 3).

\section{Histology}

The anterior segments of gonads were dominated by previtellogenic oocytes in March, but oocytes in the early vitellogenic stage were also found, indicating that the maturation process had started in early spring (Fig. 4a). Concurrently, the medial parts of gonads contained relatively high amounts of connective tissues and fat deposits (Fig. 4b), showing the 
anomalies of retrogression processes during the previous spawning season. The posterior segments (Fig. 4c) showed that most individuals were near the vitellogenic maturation stage; $60 \%$ of the examined bigheaded carps were at II/III and $40 \%$ at III/IV stage (Table 4$)$. In the ovaries from April, at least 2-3 generations of trophoplasmatic oocytes in different vacuolisation stages (e.g., endogenic and exogenic vitellogenic oocytes) were found (Fig. 4df). The extent of ovary maturation changed slightly in April compared to the previous month, with posterior ovary parts also in II/III and III/IV maturation stage, but the ratio was reversed; one-third of sampled fish ovaries were in stage II/III and two-thirds in III/IV (Table 4). In May, the maturation of ovaries could be classified in the IV, IV/V, and V/VI stages (Table 4), and several vacuolised, vitellogenic (Fig. 4g), and matured oocytes (Fig. 4h and i) were found. Postovulatory follicles were present in the posterior ovary segments of 2 individuals (Fig. 4i). In September, several matured oocytes were found in all ovary parts, indicating the capability for protracted spawning (Fig. $4 \mathrm{j}-1$ ). The posterior ovary segments, however, were characterized by diverse maturation stages (Table 4.); one individual was in the afterspawning stage (VI), one was in the early maturation stage (II/III), and 2 were in an intermediate stage between trophoplasmatic growth and nutrient accumulation (III/IV). Finally, previtellogenic (Fig. 4m), vacoulised (Fig. 4n), and matured oocytes with atretic oocytes (Fig. 4o) were found in the ovaries in November. At this time, posterior ovary segments showed that oocytes were near the end (III/IV) or at the end (IV) of trophoplasmatic growth in this month (Table 4).

\section{Genetic analysis}

Expected heterozygosity values $\left(\mathrm{H}_{\mathrm{e}}\right)$ ranged from 0.59 to 0.91 (Table 5) on different loci within the collected sample group with an average of 0.77 , whereas observed heterozygosity $\left(\mathrm{H}_{\mathrm{o}}\right)$ ranged from 0.35 to 0.87 with an average value of 0.68 . The expected and observed 
values differed significantly in Lake Balaton's stock in case of all markers (Table 5), establishing that the stock is not in Hardy-Weinberg equilibrium. The inbreeding coefficient typical for the stock (0.106) indicates moderate inbreeding.

\section{Discussion}

The aim of this study was to evaluate the evidence for and against bigheaded carp reproduction in Lake Balaton and to assess whether the individuals in the present stock are the offspring of the bigheaded carps stocked in the 1970s and 1980s or if the recruitment arrived from external sources. Although the bigheaded carp stocking to Lake Balaton was completed in 1983, these fish still have a massive stock in the lake, equal to about one-third of the total fish biomass (Tátrai et al. 2009). A recent study (Boros et al. 2014) noted that the present bigheaded carp stock in Lake Balaton cannot have originated directly from the last official or earlier stockings because the oldest fish caught in the lake over the past few years was only 16 years old. During the past decade 9- to14-year-old bigheaded carp dominated the fisheries catches, and it is unlikely that fish older than 32 years could be present in substantial numbers. Moreover, the average age of fish captured by size-selective gillnets have not changed considerably during the past decade, and fishery yields remained relatively high and constant (Weiperth et al. 2014), implying a steady source of recruitment independent of the stockings in the 1970s and 1980s.

The within-year trends of $\mathrm{I}_{\mathrm{G}}$ change show that female bigheaded carp in the lake increase their ovary masses gradually from spring until midsummer, after which a decline is typical. This trend could indicate the release of eggs during the potential spawning period that normally occurs between spring and summer in the temperate climate zone (Papoulias et al. 2006, Kolar et al. 2007). The lack of a significant relationship between fecundity (both $\mathrm{F}_{\mathrm{T}}$ and $F_{R}$ ) and sampling date, however, and the absence of bigheaded carp with empty ovaries 
suggest that ovary evacuation (e.g., considerable egg release) is not a likely explanation for the declining $\mathrm{I}_{\mathrm{G}}$. A more probable explanation is that by the end of spawning season, females resorb their eggs, resulting in fluctuating $\mathrm{I}_{\mathrm{G}}$ but no seasonal difference in fecundity values. This assumption is supported by the results of histological analyses, which detected atretic oocytes in the ovaries after the spawning season. A similar phenomenon was described by Papoulias et al. (2006) in the Missouri River and by DeGrandchamp et al. (2007) in the Illinois River, where female bigheaded carp maintained high $\mathrm{I}_{\mathrm{G}}$ values throughout the summer and resorbed their eggs at the end of the spawning season in some years. Thus, the retention of eggs may result in follicular atresia and can be induced by unfavorable environmental conditions during the spawning period.

In addition to water temperature, other environmental factors affect the reproduction success of bigheaded carp. For instance, several authors reported that flowing (current velocity $0.3-3 \mathrm{~m} / \mathrm{s}$ ) and turbid water (visibility $10-15 \mathrm{~cm}$ ) stimulates spawning in Hypophthalmichthys spp. and provides favorable conditions for egg hatching (Verigin et al. 1978, Jennings 1988, Kolar et al. 2007, Deters et al. 2012). These conditions are not typical for most of the lakes, but Lake Balaton is unique in this sense because the environmental conditions favorable for inducing bigheaded carp spawning may co-occur in some years. Because of the high surface-to-volume ratio of the lake, wind-generated turbulence can easily mix the entire water column, periodically causing high turbidity and strong currents (Padisák et al. 1990). These conditions, accompanied by optimal water temperature, may stimulate egg release, similar to that observed in May 2011. Postovulatory follicles were present in the posterior ovary parts of 2 individuals, revealing that a few mature eggs were released by some females.

The previously mentioned lack of strong linkage between fecundity and sampling date, however, suggests that considerable and bulk release of eggs is not typical for female 
bigheaded carp in Lake Balaton. In addition, the evidence of sporadic egg release does not necessarily mean the successful reproduction/recruitment, which would additionally require insemination of the eggs and then survival of the eggs and young fish. To date, there is no direct evidence for mating or for the presence of substantial numbers of bigheaded carp fingerlings in Lake Balaton. We cannot, however, rule out the chance of occasional success of complete natural reproduction because Hypophthalmichthys spp. are highly adaptive and their reproductive requirements may undergo substantial changes when introduced to a new environment (Kolar et al. 2007, Coulter et al. 2013).

Only a few and less detailed studies are available that report successful bigheaded carp reproduction under lacustrine conditions. For example, silver carp reproduced in the Gobindsagar Reservoir, India (Sehgal 1989, 1999), and Tang (1960) reported that bigheaded carp spawned in Taiwan in a reservoir with only short tributaries, but the details are unclear. These findings mandate that we reconsider and refine a previous notion that Hypophthalmichthys spp. reproduce exclusively in large rivers. Prevailing theory assumes that semi-buoyant eggs of bigheaded carp must be held in suspension by turbulence, or otherwise the eggs will sink and die embedded in the sediments (Kolar et al. 2007). Yi et al. (2006), however, found that bigheaded carp eggs survived and hatched in Petri dishes with only daily water changes and no currents. Similarly, Kolar et al. (2007) reported that field-collected bigheaded carp eggs hatched successfully in unaerated bags filled with water and sediment. Moreover, George et al. (2015) studied the hatching success of grass carp (Ctenopharyngodon idella Valenciennes 1844) eggs under experimental conditions and found that survival rates were relatively high (15\% to $35 \%)$ in treatments where eggs rested on a sand bed and lower but still notable (5\% to $10 \%$ ) when eggs were partially buried in sediment. This finding could be important because bigheaded carp and grass carp have similar (semi-buoyant) types of eggs. The fact that some grass carp eggs hatched successfully without being suspended in the 
water column suggests that bigheaded carp eggs might survive and hatch under lacustrine conditions.

Nevertheless, the genetic analyses showed remarkable deviation from Hardy-Weinberg equilibrium within the stock in Lake Balaton, suggesting that bigheaded carp do not constitute a natural reproductive community. Moreover, the analyses revealed a relatively high degree of inbreeding. These findings support the assumption that the studied bigheaded carp arrived from the nearby fish ponds through connected watercourses. These ponds have been stocked with fish from hatcheries, where deviation from the Hardy-Weinberg equilibrium and inbreeding usually occur (Eknath and Doyle 1990, Primmer et al. 1999). A further and also considerable argument that supports the occurrence and importance of bigheaded carp immigration to Lake Balaton is that Specziár et al. (2009) and Erős et al. (2012) found young $(1+$ and $2+$ age-group) bigheaded carp in the inflows of Lake Balaton after periods of high precipitation in the lake's watershed that resulted in the release of water from the fish ponds.

In conclusion, the present bigheaded carp stock (or at least the vast majority) in Lake Balaton seems to derive from external origin (i.e., from the surrounding fish ponds) rather than from natural reproduction. Occasional spawning of bigheaded carp occurred in the lake, but we found no evidence for successful hatching or survival of fry. Periodical immigration from the connected fish ponds is possibly accompanied by occasional natural reproduction, and the recruitment could arrive from these 2 independent sources simultaneously or alternately; however, immigration is apparently far more significant in maintaining the stock's biomass at a relatively constant level throughout the past decades. 


\section{Acknowledgements}

We thank Ildikó Mecsnóbel, Géza Dobos and Zoltán Poller for their assistance with sample processing and Duane C. Chapman (USGS) for assistance in manuscript preparation. Balaton Fish Management Non-Profit Ltd. provided the fish for this study.

\section{Funding}

This study was supported by GINOP - 2.3.2-15-2016-00004 and OTKA K-83893 projects.

\section{References}

Boros G, Mozsár A, Vitál Z, Nagy AS, Specziár A. 2014. Growth and condition factor of hybrid (Bighead Hypophthalmichthys nobilis Richardson, $1845 \times$ silver carp $H$. molitrix Valenciennes, 1844) Asian carps in the shallow, oligo-mesotrophic Lake Balaton. J Appl Ichthyol. 30:546-548.

Boros G, Vitál Z, Mozsár A, Borics G, Görgényi J, Józsa V, G.-Tóth L, Lehoczky I, Kovács B, Vasas G, et al. 2015. Ecological impacts of filter-feeding Asian carps (Hypophthalmichthys spp.) in Lake Balaton, Hungary. European Congress of Ichthyology. Conference Abstract: XV. Front Mar Sci. doi: 10.3389/conf.fmars.2015.03.00019.

Coulter AA, Keller D, Amberg JJ, Bailey EJ, Goforth R. 2013. Phenotypic plasticity in the spawning traits of bigheaded carp (Hypophthalmichthys spp.) in novel ecosystems. Freshw Biol. 58:1029-1037.

Cremer MC, Smitherman RO. 1980. Food habits and growth of silver and bighead carp in cages and ponds. Aquaculture. 20:57-64.

DeGrandchamp KL, Garvey JE, Csoboth LA. 2007. Linking adult reproduction and larval density of invasive carp in a large river. T Am Fish Soc. 136:1327-1334. 
Deters JE, Chapman DC, McElroy B. 2012. Location and timing of Asian carp spawning in the Lower Missouri River. Environ Biol Fish. 96:617-629.

Eknath AE, Doyle RW. 1990. Effective population size and rate of inbreeding in aquaculture of Indian major carps. Aquaculture. 85:293-305.

Erős T, Sály P, Takács P, Specziár A, Bíró P. 2012. Temporal variability in the spatial and environmental determinants of functional metacommunity organization - stream fish in human-modified landscape. Freshwater Biol. 57:1914-1928.

George AE, Chapman DC, Deters JE, Erwin SO, Hayer C-A. 2015. Effects of sediment burial on grass carp, Ctenopharyngodon idella (Valenciennes, 1844), eggs. J Appl Ichthyol. $31: 1120-1126$.

Gheyas AA, Cairney M, Gilmour AE, Sattar MA, Das TK, McAndrew BJ, Penman DJ, Taggart JB. 2006. Characterization of microsatellite loci in silver carp (Hypophthalmichthys molitrix), and cross-amplification in other cyprinid species. Mol Ecol Notes. 6:656-659.

Goudet J. 2001. FSTAT, a program to estimate and test gene diversities and fixation indices. (version 2.9.3).

Guo SW, Thompson EA. 1992. Performing the exact test of Hardy-Weinberg proportion for multiple alleles. Biometrics. 48:361-372.

Hancz Cs, Varga D. 2014. Fish culture activity in the Southern drainage basin of Lake Balaton. In: Molnár G, Farkas S, editors. Interaction of natural and social processes in shallow lake areas. International conference abstract book. Kaposvár (Hungary): Kaposvár University Balaton Research Institute. p. 37.

Jennings DP. 1988. Bighead carp (Hypophthalmichthys nobilis): a biological synopsis. Fish and Wildlife Service Biological Report, No. 88. 
Kolar CS, Chapman DC, Courtenay WR Jr, Housel CM, Williams JD, Jennings DP. 2007. Bigheaded carps: a biological synopsis and environmental risk assessment. Bethesda (MD): American Fisheries Society. Special Publication 33.

Lin Q, Jiang X, Han BP, Jeppesen E. 2014. Does stocking of filter-feeding fish for production have a cascading effect on zooplankton and ecological state? A study of fourteen (sub)tropical Chinese reservoirs with contrasting nutrient concentrations. Hydrobiologia. 736:115-125.

Márián T, Krasznai Z, Oláh J. 1986. Characteristic karyological, biochemical and morphological markers of silver carp (Hypophthalmichthys molitrix Val.), bighead carp (Aristichthys nobilis Rich.) and their hybrids. Aquacult Hung. 5:15-30.

Mátyás K, Oldal I, Korponai J, Tátrai I, Paulovits G. 2003. Indirect effect of different fish communities on nutrient and chlorophyll relationship in shallow hypertrophic water quality reservoir. Hydrobiologia. 504:231-239.

Nash RDM, Valencia AH, Geffen AJ. 2006. The origin of Fulton's condition factor - setting the record straight. Fisheries. 31:236-238.

Padisák J, G.-Tóth L, Rajczy M. 1990. Stir-up effect of wind on a more-or-less stratified shallow lake phytoplankton community, Lake Balaton, Hungary. Hydrobiologia. 191:249-254.

Papoulias DM, Chapman D, Tillitt DE. 2006. Reproductive condition and occurrence of intersex in bighead carp and silver carp in the Missouri River. Hydrobiologia. $571: 355-360$

Primmer CR, Aho T, Piironen J, Estoup A, Cornuet J-M, Ranta E. 1999. Microsatellite analysis of hatchery stocks and natural populations of Arctic charr, Salvenius alpinus, from the Nordic region: implications for conservation. Hereditas. 130:277-289. 
Raymond M, Rousset F. 1995. GENEPOP (version 1.2): population genetics software for exact tests and ecumenicism. J Hered. 86:248-249.

Rousset F. 2008. Genepop'007: a complete re-implementation of the Genepop software for Windows and Linux. Mol Ecol Resour. 8:103-106.

Sakun OF, Butskaya NA. 1963. Opredelenie stadii zrelosti i izuchenie polovykh tsiklov ryb [Determination of maturity stages and study of sexual cycles of fish]. Moscow: VNIRO.

Sály P, Takács P, Kiss I, Bíró P, Erős T. 2011. The relative influence of spatial context and catchment- and site-scale environmental factors on stream fish assemblages in humanmodified landscape. Ecol Freshw Fish. 20:251-262.

Sehgal KL. 1989. Present status of exotic coldwater fish species in India. In: Mohan JM, editor. Exotic aquatic species in India. Special Publication 1. Indian Branch: Asian Fisheries Society. p. 41-47.

Sehgal KL. 1999. Coldwater fish and fisheries in the Indian Himalayas: rivers and streams. In: Petr T, editor. Fish and fisheries at higher altitudes: Asia. Rome: Food and Agriculture Organization of the United Nations Technical Paper 385. p. 41-63.

Specziár A, Takács P, Sály P, György ÁI, Erős T. 2009. A Balaton és befolyói halállományának monitorozása az EU VKI irányelvek figyelembevételével. [Monitoring of fish stock of Lake Balaton and its inflows in accordance with EU WFD.] In: Bíró P, Banczerowsky J, editors. A Balaton Kutatásának 2008. Évi Eredményei, Budapest: MTA. p. 73-83. Hungarian.

Tang YA. 1960. Reproduction of the Chinese carps, Ctenopharyngodon idellus and Hypophthalmichthys molitrix in a reservoir in Taiwan. Jpn J Ichthyol. 8:1-2.

Tátrai I, Józsa V, Boros G, György ÁI, Héri JA. 2009. Balatonba telepített halfajok biológiai szerepe és hatása. [Impact and role of introduced fish species in Lake Balaton] In: Bíró 
P, Banczerowsky J, editors. A Balaton Kutatásának 2008. Évi Eredményei, Budapest: MTA. p. 63-72. Hungarian.

Van Oosterhout C, Hutchinson WF, Wills DPM, Shipley P. 2004. MICRO-CHECKER: software for identifying and correcting genotyping errors in microsatellite data. Mol Ecol Resour. 4:535-538.

Verigin BV, Makeyeva AP, Mokhamed MIZ. 1978. Natural spawning of the silver carp Hypophthalmichthys nobilis, the bighead carp Aristichthys nobilis, and the grass carp Ctenopharyngodon idella in the Syr-Dar'ya River. J Ichthyol. 18:143-146.

Weiperth A, Ferincz Á, Kováts N, Hufnagel L, Staszny Á, Keresztessy K, Szabó I, Tártrai I, Paulovits G. 2014. Effect of water level fluctuations on fishery and anglers' catch data of economically utilized fish species of Lake Balaton between 1901 and 2011. Appl Ecol Env Res. 12:221-249.

Xie P, Liu J. 2001. Practical success of biomanipulation using filter-feeding fish to control cyanobacteria blooms: a synthesis of decades of research and application in a subtropical hypereutrophic lake. Sci World J. 1:337-356.

Yi B, Liang Z, Yu Z, Lin R, He M. 2006. A study of the early development of grass carp, black carp, silver carp and bighead carp of the Yangtze River. In: Chapman DC, editor. Early development of four cyprinids native to the Yangtze River. US Geological Survey Data Series 239. p. 15-51. 
Figure. 1. Catchment area, the main inflows, and the fish sampling locations (marked with triangles) in Lake Balaton. (I) Lake Balaton; (II) Kis-Balaton Water Protection Reservoir; (III) Marcali-reservoir. Main inflows of Lake Balaton: (1) Zala River (139 km in length); (2) Nyugati Canal (17 km + connected brooks); (3) Pogányvölgyi Canal (40km); (4) Egervíz Stream $(32 \mathrm{~km})$.

Figure. 2. Ovary of a Hypophthalmichthys sp. individual caught in Lake Balaton showing (a) anterior segment (closest to the head); (b) medial part; and (c) posterior segment (closest to the genital pore).

Figure. 3. Seasonal variation of the gonadosomatic index $\left(\mathrm{I}_{\mathrm{G}}, \%\right)$ values in female bigheaded carp and the water temperatures at each sampling times. Plots marked with the same letter within the same year do not differ significantly $(p<0.05)$.

Figure. 4. Cross-sections of bigheaded carp ovaries sampled in Lake Balaton Descriptions: $\mathrm{oa}=$ atretic oocyte $\mathrm{pf}=$ postovulatory follicle; $\mathrm{ft}=$ fat deposits $($ connective and fat tissues); om = matured oocyte; op = previtellogenic oocyte; ov = vacuolised oocyte; ove = endogenic vitellogenic oocyte; ovz = exogenic vitellogenic oocyt. 
Fig. 1.

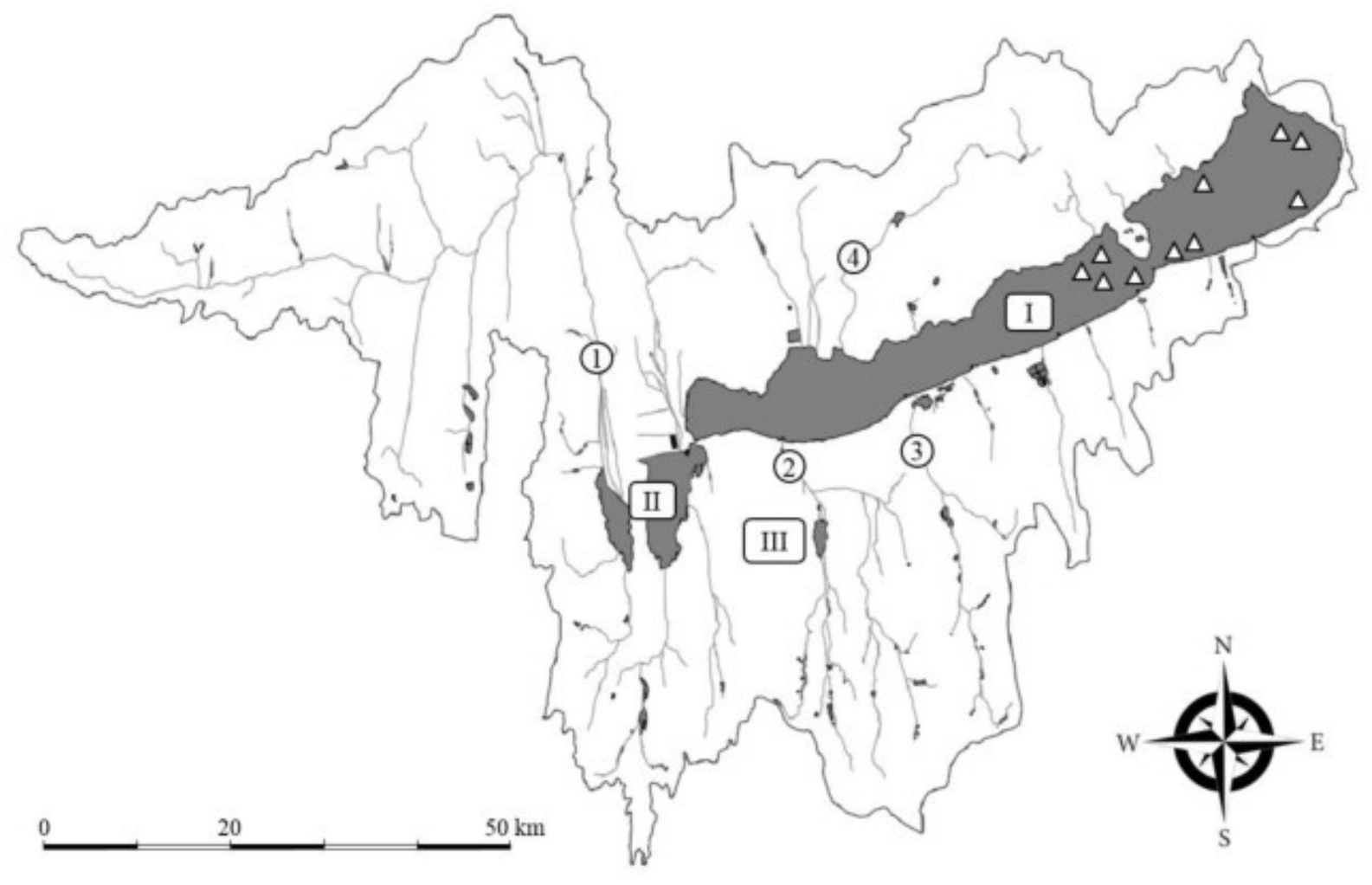


Fig. 2.

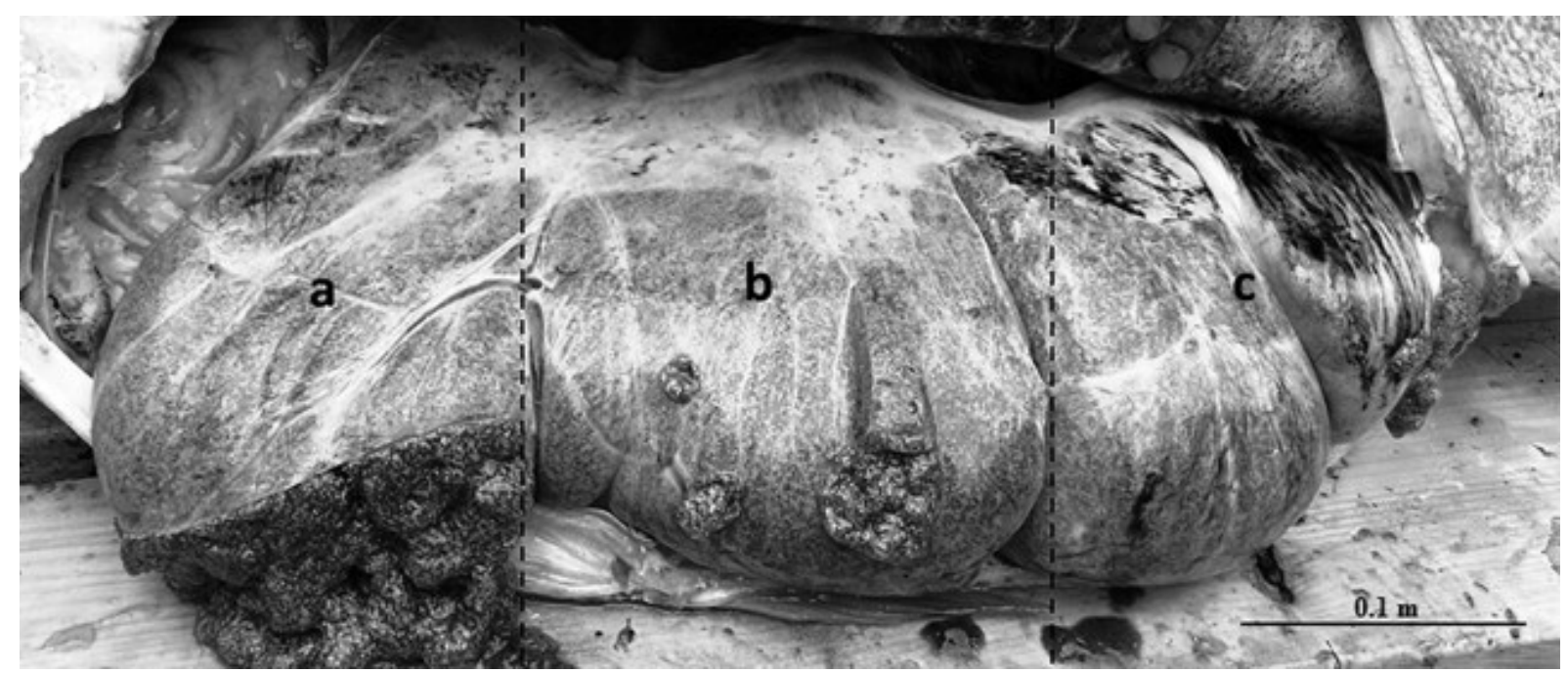

Fig. 3.

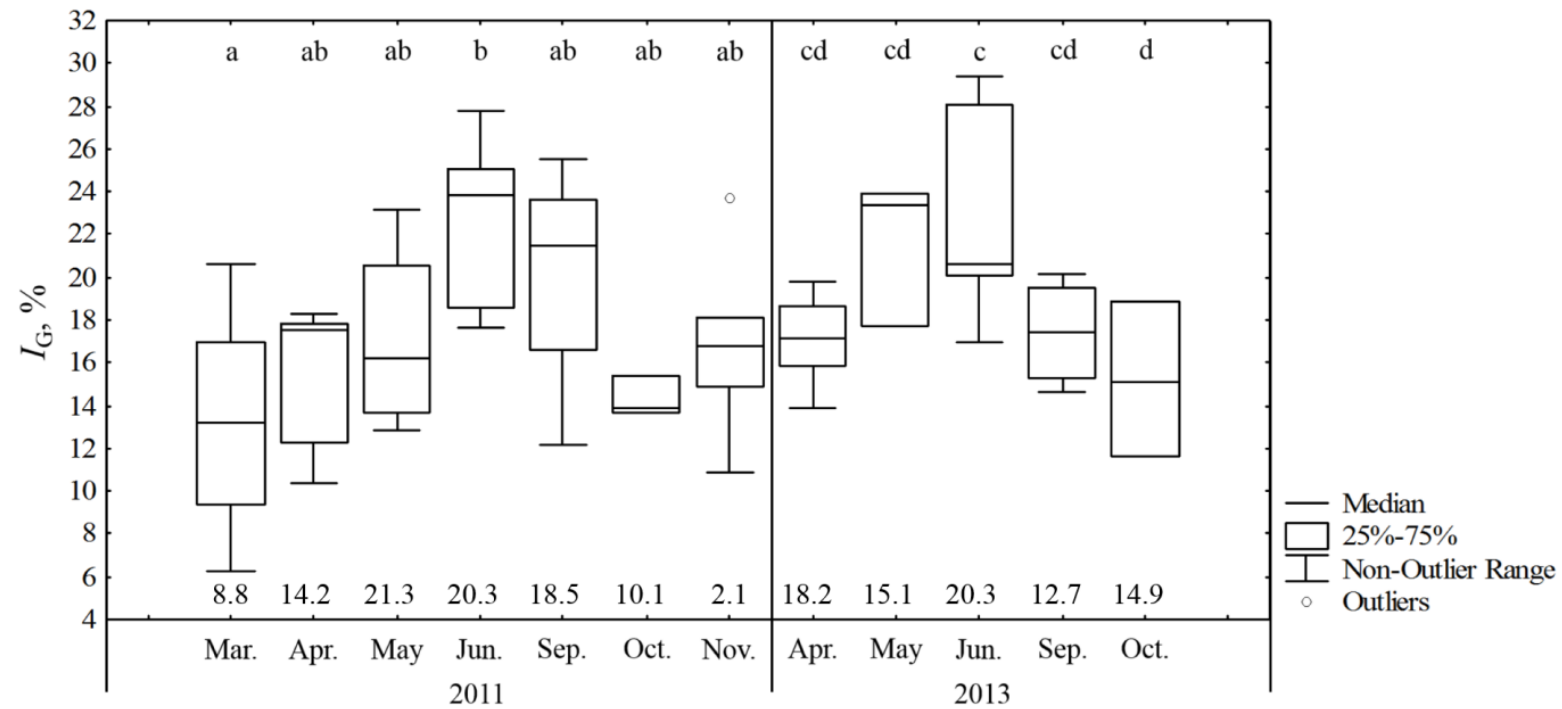


Fig. 4.

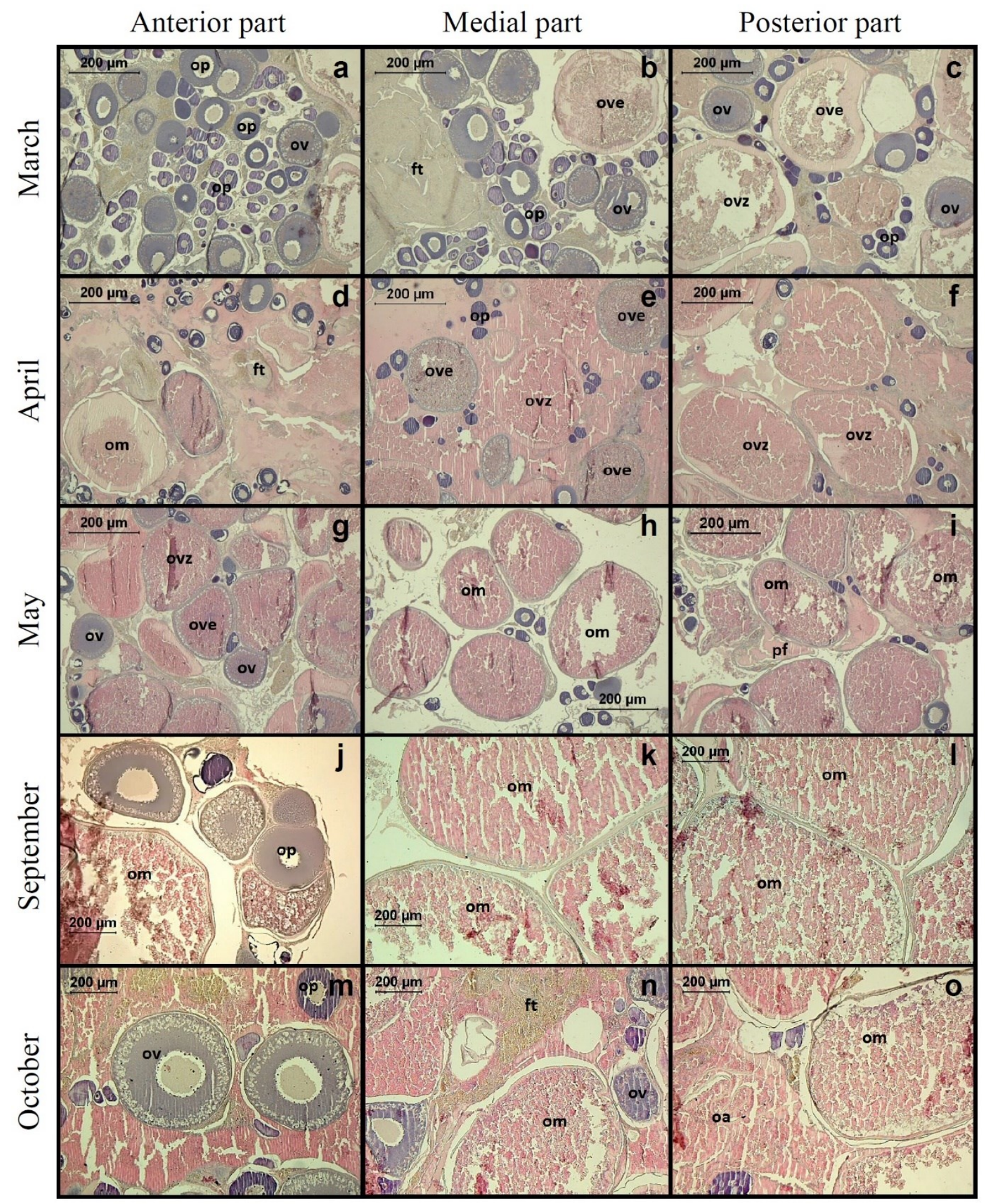


Table 1. ANCOVA models testing the effects of standard length $\left(\mathrm{L}_{\mathrm{S}}\right)$, wet body mass $\left(\mathrm{W}_{\mathrm{T}}\right)$, and Fulton's condition factor $(\mathrm{K})$ on the gonadosomatic index $\left(\mathrm{I}_{\mathrm{G}} ; n=49\right) . \beta=$ standardized regression coefficient; $R^{2}=$ adjusted determination coefficient of the model

\begin{tabular}{lllllll}
\hline $\mathrm{I}_{\mathrm{G}}$ & \multicolumn{2}{l}{ Covariant } & \multicolumn{3}{l}{ Sampling date } & \multirow{2}{*}{$R^{2}$} \\
\cline { 1 - 6 } & $\beta$ & $F_{1,37}$ & $p$ & $F_{10,37}$ & $p$ & \\
\hline $\mathrm{L}_{\mathrm{S}}$ & -0.0734 & 0.2703 & 0.6062 & 3.2148 & 0.0045 & 0.3101 \\
$\mathrm{~W}_{\mathrm{T}}$ & -0.0730 & 0.3061 & 0.5833 & 3.2455 & 0.0042 & 0.3107 \\
$\mathrm{~K}$ & 0.0633 & 0.1493 & 0.7013 & 3.1827 & 0.0048 & 0.3078 \\
\hline
\end{tabular}


Table 2. ANCOVA models testing the effects of standard length $\left(\mathrm{L}_{\mathrm{S}}\right)$, weight $\left(\mathrm{W}_{\mathrm{T}}\right)$, and Fulton's condition factor $(\mathrm{K})$ on total fecundity $\left(\mathrm{F}_{\mathrm{T}} ; n=18\right) . \beta=$ standardized regression coefficient; $R^{2}=$ adjusted determination coefficient of the model.

\begin{tabular}{lllllll}
\hline $\mathrm{F}_{\mathrm{T}}$ & \multicolumn{2}{l}{ Covariant } & \multicolumn{3}{l}{ Sampling date } & \multirow{2}{*}{$R^{2}$} \\
\cline { 1 - 6 } & $\beta$ & $F_{1,12}$ & $p$ & $F_{4,12}$ & $p$ & \\
\hline $\mathrm{L}_{\mathrm{S}}$ & 0.3930 & 1.8322 & 0.2008 & 1.3419 & 0.3105 & 0.0257 \\
$\mathrm{~W}_{\mathrm{T}}$ & 0.3744 & 2.2607 & 0.1585 & 1.2656 & 0.3364 & 0.0550 \\
$\mathrm{~K}$ & 0.0546 & 0.0217 & 0.8851 & 0.4915 & 0.7422 & 0.1209 \\
\hline
\end{tabular}


Table 3. ANCOVA models testing the effects of standard length $\left(\mathrm{L}_{\mathrm{S}}\right)$, weight $\left(\mathrm{W}_{\mathrm{T}}\right)$, and Fulton's condition factor $(\mathrm{K})$ on relative fecundity $\left(\mathrm{F}_{\mathrm{R}} ; n=18\right) . \beta=$ standardized regression coefficient; $R^{2}=$ adjusted determination coefficient of the model.

\begin{tabular}{lllllll}
\hline $\mathrm{F}_{\mathrm{R}}$ & \multicolumn{2}{l}{ Covariant } & \multicolumn{3}{c}{ Sampling date } & \multirow{2}{*}{$R^{2}$} \\
\cline { 1 - 6 } & $\beta$ & $F_{1,12}$ & $p$ & $F_{4,12}$ & $p$ & \\
\hline $\mathrm{L}_{\mathrm{S}}$ & -0.4108 & 2.5242 & 0.1380 & 0.8650 & 0.5123 & 0.2275 \\
$\mathrm{~W}_{\mathrm{T}}$ & -0.3715 & 2.7694 & 0.1219 & 1.2055 & 0.3583 & 0.2403 \\
$\mathrm{~K}$ & 0.0812 & 0.0579 & 0.8137 & 0.9100 & 0.4888 & 0.0695 \\
\hline
\end{tabular}


Table 4. Maturation stages found in posterior ovary segments of female bigheaded carp $(n=$ 23).

\begin{tabular}{lllllll} 
Month & Fish 1 & Fish 2 & Fish 3 & Fish 4 & Fish 5 & Fish 6 \\
\hline March & II/III & II/III & II/III & III/IV & III/IV & - \\
April & II/III & III/IV & III/IV & III/IV & II/III & III/IV $^{\mathrm{a}}$ \\
May & IV & IV/V & V/VI & V/VI & - & - \\
September & II/III & III/IV & V/VI & III/IV & - & - \\
November & III/IV & IV & III/IV & IV & - & - \\
\hline
\end{tabular}

${ }^{a}$ Quantitative domination of endogenic-vitellogenic oocytes

${ }^{\mathrm{b}}$ Postovulatory follicles were found in posterior part of ovary 
Table 5. Observed $\left(\mathrm{H}_{\mathrm{o}}\right)$ and expected $\left(\mathrm{H}_{\mathrm{e}}\right)$ heterozygosity values of bigheaded carp stock in Lake Balaton and the significance of difference ( $p$ value) $\mathrm{H}_{\mathrm{o}}$ and $\mathrm{H}_{\mathrm{e}}$.

\begin{tabular}{llll} 
Locus & $\mathrm{H}_{\mathrm{o}}$ & $\mathrm{H}_{\mathrm{e}}$ & $p$ value \\
\hline 1 & 0.7359 & 0.6857 & $<0.0001$ \\
2 & 0.6604 & 0.8058 & $<0.0001$ \\
3 & 0.6038 & 0.7595 & $<0.0001$ \\
4 & 0.7196 & 0.8925 & $<0.0001$ \\
5 & 0.8426 & 0.8889 & $<0.0001$ \\
6 & 0.7593 & 0.6151 & $<0.0001$ \\
7 & 0.6887 & 0.9104 & $<0.0001$ \\
8 & 0.3585 & 0.5962 & $<0.0001$ \\
9 & 0.8785 & 0.7894 & $<0.0001$ \\
10 & 0.6132 & 0.8365 & $<0.0001$ \\
\hline
\end{tabular}

